
THE

\title{
MEE-KEEPLIR'S GUIDE
}

\author{
TO MANAGE BEES
}

\author{
IN THE
}

\section{VERMIONT BEE-HIVE.}

\begin{abstract}
B Y JOH N M. WEE K
Weat Farms, Satisbury Vt.
\end{abstract}

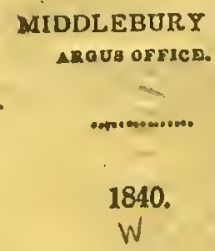




\section{$5 F 523$ W394}

\section{PREFACE}

The proprietor of tho Verniont Bce Ilivo lios fonnd it necersary 10 publish o conciac guido for thuse who ano llis live, by whichtliey may cullivato their bece wilhout being compelled to reud so extenxive a work oe thio autlior's Manual on becs. Y (i, every A piaj. an, who has a taste for the naturul history of tineso little industriuns insecls, sliould own some treatiso on tho sulject of becs, which will dirce his atten. tion to the preculas instincls of llicir nulures, and hab. Its, which might ofluewise remain unthought of. Ton thousand of the author's Manualo on bec's havo gono brfore the public in several successivo cditions, inco IE36, and another cdition revised ond enlarged is culled lor.

The trials already made in tho use of tho Vermont Beo Ilivo in variolls scctions of the United States, has abundantly proved its kuperior advautages: andit is believed that no bee namager will ever regret that ho has mode a failliful trial if tlis live, if ho strictly adopto tho principlo of inunaging his bee in accordance with my Minuol.

\section{THE AUTHOR.}

Entercd according to act of Congrese in the jear 1810-By Јона M. IV zexn, West Furmo, Solisbury. $V t$. in tho clerk's office of the Districs Court of Var. nont.

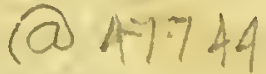




\section{Chatten 1.}

On the constavctium or a ae grm.

A Bec II ive sliould be mado of sound bos rds woll seasoned, at loast ono inch thick, with tho chambet floor lot into the sides and front beards by a groove, and tho hive well and thoroughily nailed together wo as to prevont the boards from wa:ping, particularly tho upper sive of tho elsaniber floor whoro the draw. ers are placed, to prevont nny vacart placo betwixt the boltom of tho drawer and floor under it for worms or moths to secrcte themsclves from the notico of the bees. As tho vapor of tho bers, in cold weather swella thu timbor in the inside, noso than the out. sisle, the bee manages will readily account for the crackn which appoar in liven that have been usod for bocs ono or moro yeurs, All cracke and open jointe whould be filled with a composition mado of Beus. wax and Wheat flour simmered together which ro. aists all iuscels.

The luwer apartment of a beo live slsould liold one buslicl, and tho chansber about ono third as much. This sizo carnot be doviated from to any considera. ble extent with safety. Nature has its fixed prin. ciples whicls are unalternble by liuman wisdom. Not. withstandiug my letter patent gives the purchaset tho privileve of altering the livo in s/sape or sizo to auit limelf (retaining tho principle of tho patent,)

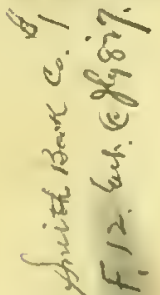


yet it is found by varions and repeated trials, that this siee is the most profituble. The drawers aro number. ed corresponding will the quilut ity it takes to fill the chamber, to wil, No 1 is 12 and $1-2$ inches wide, 14 inches long, and 6 inehes high when finished, and fills tho chumber very lonso so as to rendor its removal easy whon necessary. This drawer should never bo usod oxcept for trunsferring becs, and dividing them inasmuels as its size will enable the swarm to locate in 1t, raiso young becs, deposit bread, and thus defeat the whole design of the chamber which is to procure puro honey unadulterated by any organized operation of tho bees.

The eltamber of the hive is 13 inches wide, $14 \mathrm{in}$. -hes decp and 6 and $1-4$ incher high in the clear.

No. 2 drawers aro 6 and $1-4$ inches wide, 14 in. che long and 6 incles high on thooutside when fin. ished, two of which fills tho chamber, and are the most profitable wood boxes for ordinary uses, inasmuch as bees will make more honey in these sized drawers than any other.

No. 4 drawers aro the samo size of No. 2, meven in. shes long only. No. 8 drawers aro the same size a No 4.. half the wid:h only. No. I6 aro half the size of No. 8, half tlieir height only, with an aperture througl the top as well as the bottom of the lower box, as ono is placed directly over tlie othor when in the hive. All drawors of a smaller size than. No. ?, 
- honld be made ivitl, glass sioes and'ends and no. drawers or hoxes of less size llan $\mathrm{No}_{4}$ should bo used for any purpose "xeopt for curiesily. Tha bee manager will not often obtitin any lioney in ith top box No. 16 unless lie nttisehes eumb to the under side of the cover of the same, whiels is easily done by fittering on a littlo melterl bees wax, then carefully stick on tho bit of empty eomb.-It is finnd by doing this that tho labors of the bees are greatly farilitaled in any drawer. Whell bits of comb are tlits attached to the top board the bees will make more homby in a season on accoum of the ex!rente diffic ulty uf making tho wax adhere to the new wood at their enmeneenent inasmuch as this difliculty is partually removed by this process; besides, the A piarian can give his bers a direction in building their combs by the pices lie attaches to the box. A hivo should be planed sinooth insido and ou: and painted, or whitowashed with linno ou its outside. The inside should bo rubbed with cold bees wax and tho under side of the chamber flour should be scratched with a sharp seratch so as to raise littlo ridges to onable the bees to hold on without falling suddenly upon the bottom board. As une of the most impo-tant uses of sticks ill a bee hive is in sustain the woight of the boes whilo they are building down thei combs, it is believed that boards 3 inches wide in the centre ta. poring nearly to a point at each ond, is not too wide and ohould be placed in tho best possiole manner to 
sustain the weight of the bees as also that of the new combs which aro always oxeceding tender a well as softenci by their auinal heat almost to melling, $10 \mathrm{en}$. able tho becs to build on, alld culurgo tho samo at pleasure.

That tho bottom board slould bo suspended and brought ander tho control of tho button will bo reads ily seen when treated of iu its proper chapter.

\section{CHAPTER 2.}

\section{ON SWAIMING AND HIVING.}

Thero aro so great a variely of methods adopted by theo managers to calch swarms when they sally forth I shall mention but two or then which will bo found in tho appendix on the last pages of this work.

Every apiarian should have his hives in readinese, elean, dry, and cool, witl their appendiges in their places-drawers liotlom up, or slides undir them, to prevent entrance. When a swarm comes forth and has olighted, tho hive should be set on a broad table, or baard with a billot of wood placed under tho back side, so as to bring the hive nearly level. Now cut off the limb and elake the bees on tho tablo by tho eide of tho livo which may be set over then, or atnd as already placel; for tho beos will certailly find tho hive, inasmuch as tho limb is trison from tho troo 
whero they alighted: as soon as half of tho bees aro in the lave, set it in a light portable frame madu for that purpose, and leitcli on the boltom board; now set the frame and hive on the table, taking earo to brush tho remaining bees that are yet left on the tablo into. thic air. In this way tho bees will ba principally in tho hivo in from six to ten minutes. It should bu rumarked however that if the Queen is gech sho should be talien carefully in tiae lakd and placed un tho bot tun board, for slic is usually heavily ladell witl eggs if it is a first swarm from a livo in 8 we season, and cliould be handled very tenderly. Now bring the bot. tom board under the control of the button, und close tho hive except tho common cntrance, and placo it whero it is intended to stant through the season. In caso unany swarms are expected in a day as from large estublishments, acveral low tables are necessary which -hould be covered wills a slicet which noy bo folded over tho hivo by drawing up lhe corners, then tho hivo of bees may be carried away some distanco whilu another swarm aro cullecting in a budy, and thus, doubling prevented, for as soon as anutherswarm has alighted, they may bo shaken off, tho hive set over them and tho becs confined by the slieet and carried o few rods in anotler direction. In case is becomer necessury to invert tho hivu to tako tho bous from the body of a treo, or from ang otlier causo, tho drawers hould bo confined in their places to prevert tho beer 
fromfalling through the apertures into thu clamber, as they will be callght betwixt the boxis and chamber florr. In alt such cases I pretier u light sq" ", lc basket (not too doep) wullowt handles, into whise it the bees may be shouk, or brusliud as the case thiy require, when a cleth liay bis thrown over tlie whiut alod cat. ricd any destrable distiance fur the live.

All swarms of beces weighing over sinvelu pourds should havo access to llie druwers at the llan uf hiv. ing; smaller ons should bave entrance 11. won or

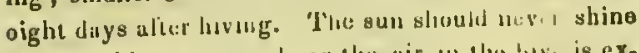
on a bee hive mismuch as tho air m the hiv is ex. hausted of a great portion of its vitality il a $l_{\text {. }}$ w min. utes in a hut day, und the bees are preventio from their regular work, and is fiequently the kuse of young swarins leivnng the hive for the ivouds - lsence a swarm of bess should be placed in the apary the

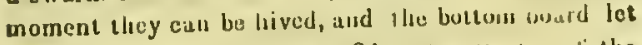
down 3-8 of an inch on tho $3 \mathrm{~d}$ or lourtis say if the weather is hot. As thas been iny invariate pracs tice to secure nyy linves from thu rays of tho sun, whilo hiving the bese from time out of inind, ind a ave never nade any woises uncummon to thum when owarming, nor perfumsd my hives witl any thung exs copt rubling tlie insido of now lives witl cold booswax so that the becs could stick and not fill sudtenty apon the botloun buard, and havo never lout a single -warm by flight to tho woods whon I was present at 
thiving. It is true indeed that swarms havo been known to leavo tho old stock and go direct to the woods without alighting ; but one man alone is able to stop them in case they crose a ploughod field or in any placo whero dirt is oasily obtained; by throwing a few landfuls of dirt angling among tho leaders (which are always forward at such times; they are soon s'vayed out of thoir true line, and as they havo no rolling eyo like man, and quadrupeds, they aro confused at once, and are compolled to alight, and reorganizo ba. fore shcy can procoed on their journoy. - It is of no use to throw dirt into thomain body of the swarm, for, before bees leavo for the woods they sendiout an em. bassy to seek out a residonco, and theso messongers on their return, become leaders and fiy forward; all the rest follow.

Bees froquently swarm out, and return back to the old stock its a fow minutes-their return is causod by the inability of tho Qucon, as in stich cases she is usually so heavy laden with eggs that she is unable to fly, or aoon tires out.- I lavo oflen found her on the outside of tho hive, or within a few fect of it, she should always bo looked for, and found if possiblo, for, unless she is able to return to tho hivo again, the beos will not swarmantil another is halched, which is not often sooner than 8 days after first swarining. Now as the swarming scason is tho best part of the jenr for bees to collget honey, the roador will seo that no rime should bo lost in sivarming, inasmuch as overy 
day throws them into proorer and less abundant fued.

In case the Queen is not found and does not return, in large cstabliskmonts the evil is easily remedica by catching a quecu from any small swarm and introdu. cing lier at the mouth of the live. $\Lambda$ stock of bees will receive any gueon that is offered them when they are destitute, and in this case as well as all others the old queen leaves the live with the swarm and the hive is left destitute until another can be hatclicd. I have often supplied lives under sucli circumstances witls a queen which has usually brought out tho swarm in the course of a day or two.

CHAPTER 3.

ON VENTILATING TLE HIVE.

A judicious ventilation of the hive is one of tho most intricate and difficult duties of the apiarian: Inasmuclı as becs need more air in very hot and in very cold weather than ab any other timo: to ficili. tate this part of boo management, the bot!om board is suspended and brought under the control of the button. It is found by experienco that in warm weather, when honey is collocted in tho greatest a. bundanco there is an insuficiency of air pressing through the aperture into the drawer to facilitatc the labors of the bces in the boxes unless tho bottom bonghd is lo: down a little to receivo the air from bo. 
Iow, and yel, in chilly weathro unless the botton hoard is closed up, there is danger of destroying the ehry. salis by a chill; hence the beo manager will see the propriety of closing up the bottom board at every cold turn of weather during the breoding senson, which, iil Vermont usually lasts finm April to hato in Sep. tember.

\section{CHAFTEU 4. \\ ON PREVENTING HOBBERIES.}

Bees rob euch other when but littie or sto honey caube obtaned and at no other time: to prevent this, the bottom board should be brought under the con. trol of the button and the live kept closed until honey is casily oltained from blossoms, loaving the month of the hive open only. As the cutrance of the hive is inade by boting 7 holes with a centre bit 3-8 of an inch in diamcter, not larger, 2 or 3 inches from its bottom, the reacler will see at once that theso holes are casily guarded by the bees as the ventikator is to bo closed exeept ill very hot, and in cold weather.

f The bottom bourd should be let down ones nr twice is week and eloarcd to keop any webs from forming be. twixt that and tho edges of the hive. The bottom board should be white washed with line every spring as the begs are very foud of it and is very conduçive to thoir licalth. 
When it is found that robbing is commeneed and continued with groat earnsstucss their manager should sprintslo the robbers as they coms witl cold vatc1, the culder tho wa:cr is. this better, as it will soon frigliten them into peace. Many bses may fall and sesm to ba drowned, but they will resuscitate and re. turn homo without any plunder.

It is proper here to remark that tho apiarian may mako a mistake and sprinklo his bees when the queen is taking her excursions in tho air which always produces great tuniult and confusiun about the hivo as well aw when engaged with hostile foes. As a sure indicntion of robbery the observer will see little bits of comb whieh are the capings of cclls on the bottom board that aro torn off by the robbers to get tho honey.

\section{CHAPTER 5 .}

\section{ON EQUALIZING COLONIES.}

As overy live and all their appendages should be marle exactly alike so as to prevent mistakes and diffeulties in inanaging the bees it is proper that colonies should bs equalized, which is done with perfoet eace in the following inanner, viz :

Hive one swarm in the lower apartment of the hive; collect another swarm in a drawer, and insert the same in the chamber of the hive contain. ing the first. 'Then if the swarns are small, col. 
lect another small swarm in aundlap drawer. alld

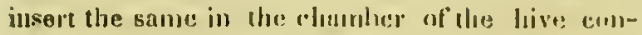
taining the first, lyy the sinle of lloe seconte. In oase all the bees from eillur of ilus diawers, nuisgle and go helow will tho fiss switrut and leidse libe drawer empty, then it may lw: ronoved, ands

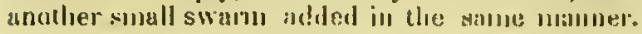

As separate swarins of bers hecomu: lonstils towitrils

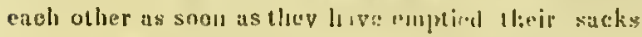
and formed a wational elatacter hy acturiring rightes. of property, it inay become necesary to fomigules each swarm with a littlo tobace smolie in prile: (1) render a sarueness in their seent whici prevents them from distinguishing euch other fiom their nwn companions: Iil this way old swarns may be unitcd at any proper seasou of the gear-young swarms uay be united at ally timo within 4 dayss after swarming without smoke. Sccond swurms only, shculd be doubled, $3 \mathrm{~d}$ and $4 \mathrm{~h}$ swarnis should alwiys have their queenstakon from thom and the bees will rotnen 10. the parent stock, as will be treated of in its puoper elaptor.

\section{CHAI'TEIR 6. \\ ON REMOVING HONEY..}

Insert a slide under the drawer, so far as to cut? off all conmunication between the lower ajartinent and the drawer IIsey anotherelide betwcels: 
the first slise and the drawer. Now draw out the lox comeaniner the lonery, with the slicle that is 11+ Xt lo it.-Sol the douser on its wiurlow end, a

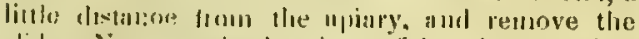
slicke. Now sialply lla fimes of the drawer, this relloveal, wish an enully one, and drats the first insiried slide.

If there is dauger of tho bres carrying back the houry, or of the hex being robbed by ether hees; "take: all empry harei with one head ont, and a

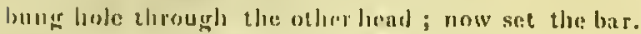
icl over the arawer which so darkens the interior of lhe barrel where the box of linucy remains that the bees are unulite to return after they hase eseaped ibrough the hung hole. In this way the hee manas ger can pursur lis commol: business withoulteing in danger of lusing his honey."

\section{CHAPTFK 7. \\ OX TRANSTERRNG BEES.}

'Tlis operation should never be performed so long as the bees are doing middling well. 'Plo best mesh. of of transferming fiom the old fistioned hives is as follows. Immediatcly : forthwith, ifter hiving a swirm from tho old stack to he transferred, set tha new nive containing the swarm as near as possiblo where the old ono stood, having removed that a few yards in front. Now take all the comb, lioncy, and 
bees out of the old hive. Tles bees wili all return and enter the uew hive. Put on at veil and at prail of woul len gloves to prevent stings: their hostility will snou erase, for they will yicld to their master's wishes in? or 3 misutes after he eommenees laking away their comb and tho veil and mittens unay bo disprensed w th. liut there is another method which I very anueh hase in transterrmg bers from one Vormout hiro to another of the same kind.- It is this :

This operation should never be effected by compulsion.

First Method.-Insert dralwer Nu. 1 into the chamber of the hive tobe transferred, as carly as the first of May. If the bens fill the chatwer, they will recede from the lower apartinout and winter in the drawer. As early in the sprung as the bees earry in bread plentifully on thoir legs, removo the drativer, which will eoutain the principal part of the bees, to all ompty hive. Now romovo the old hive a fow feet in front, and pluce the new one eontaining tho draw. er where the old ono stool. Nnw turn the old hivo bottom up. If there are any bees left in the old hive, they will soun return and take possession of their new babitation.

Second Meruod-Take drawer No. 1, well filled by any hive the same season--insert the same into tho charaber of the hive to be transferred, in Sejtember, (August would he better). If , 
the bers nech tratsferring, they will repair to the - fruwer und unke like same their winter qunrters.

Then propeed in the spring as directed in tize - first methuil.

\section{Cinapter 8.}

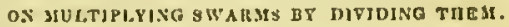

The: Inrge drawar, No. J, should always be used - for this purpuse. Insert slicles, as in Chup. 6, and remove the driawer domlaining bees and hrood- comb, place llic: sames in the chamber of un conply

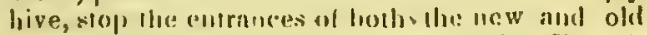
lives, taking care to give them nir, as in Clap. 4. -Give cle:ull water daily, three or fom days. Now te: the bese, in hom hives, have their liherty.

'llie noly propuer time; 10 divide bees is just be* fore first swarming.

\section{citapter 9.}

ON PREYENING THE HOTHS.

The Bee House and bottom board (if not hives) should be weil washed over inside and out evory spring with white wash mado of lime which is a groat proventive of the moths as well as spiders and othes insects, at the same time it eonduces vory inuch to the hoalth and vigor of the bees. Let down the bot. torn board ouse or twice in each week and see that.ne 
flth nor web collects-atrow on a littlo fino salt occosionolly, until the hive gets wnll replenished witb boes. Tuko the queeny from all tho littlo swormsand lot the boos roturn to tho parent atock to keep it well guarded from millers and roblers ond also to keep up tho animal hoat so nocessary to keep tlie in from per. labing from culd in tho wiuter. It is not unnsual for thess small swarms to sally out several tunes until all thoir queens are liatelied, und os this part of beo monagomont constitutra an iumprtaut luaturo of my sye. tom of managentent, it is lioped that every apiarian will persevero in this particular until ho realizesits benefits. No sirarm of boce in 4 well construeted and woll uado hive willever inaterially suffir by tho mothe molong an they aro woll stocked witls bees and thoy hava a liring and thisful queen.

\section{chapten 10. ON VEEUUMO BEES}

Bives of boes weiglting lese than 30 pounds in addition to the weight of tho hivo, should be fed in Oosober, as they will ot that tisse, whon tho weatlier is warm, store awily tho honey in such a unouness as will bo most convonient lior thu.ll in the wintor. 'l'hn feo* der an dencribed in my Manual moy bo coed, or lake a inch bonrd 10 inclies wide and 14 inclies long, liwh 
low out the upper sidlo so as to causo tho honey to' gottle to its centro; now lay on comb filled with hon oy filtered into tho colls (West Inctia honey is as good as any) remeve the drawers and place it in tho chamber of the hive: one picce of comb may bo laid over anothor, thus filled, until tho chamber is nearly full -I have known a single swarm to store away $10^{\prime}$ pounds in a day and night. The bottom board and ventilator should bo closed at this time, and if thero aro but few becs, one or two of the lioles at tho live's moutls should be stoped so as to cnable tho bees to guard their entrance, and resibt their enconies.

A hise of ises should weigh at least 25 pounds more than the weight of tho livo on the first of Decembor.

\section{chapter 11.}

ON WINTERING DEES.

When I have let my bees stand out, I have suc. coeded best iu wintering $t / 1 \mathrm{~cm}$ by suspending the bots tom board at leust an inch from tho hivo and" kept the fontilator open. I lavo kept about sixty sivarms in a dry cellar mado in tho side of a hill several seasons wilhout loosing a single swarm and yet I have found come nrouldy combs in somo few of the lives in the spring which his indued mo to construet an apiary at cousiderablu expeliso which will answer for sum. ner and winter and save the trouble of much hard 
Plabor in moving my bees as also to prevent any mould from enllecting on the combs. My apiary is con. structed for E2 hives 18 feet aquare, 3 storics high, or rather 3 tiers high, 3 feet 2 inehes betwixt joints, with a projection two feet wide on tho outside to keop tho rays of tho sun from tho hives and also to keep tho bees from nuingling : sliclves on tho inside 18 inches widc, on which, resta are creeted to suspond the hives: slutters or doors on the outside, which closo in so as to render tho roum perfsctly darls in the winter and whou open gives tho bees all the light in summer: Doors on tho inside folding against tho hives in tho suminer to prevent any rake of wind to blow away tho boes to perish whon they altempt to alight, in chilly weatler. A storo is planted in tho winter which may be licated up as ocession may rev quiro to thaw out tho frost in the hives, and cnablo tho becs to novo at loisure into any part of tho hive; tho moutli or cutranees of the hive aro stopped; ven. tilator covered with a wire serecm, and a box 4 or 5 inches decp matlo watcr tight and to fit the bottoms of each hive, with a wire serecn on the back sido an inch or two widlo to admit air, is slippod under, and confin. ed in its place as tho bottom board is taken off, so that no bee cun cscapo tlıo hive until I am ready to - let thoni out in some warm turn of weather, when I am guro that the atmosplsero will admit of their aafo , relurn. Thesebozes receivo all the water caused by 
tho exlsalatlons of the bece, together with other filtb which is casily removed in tho epring and the bottom bourde rentored to their places.

I am inclined to think tliat a beo bouno mado for two tiars of hives on two side of tha hall any deaira. blo length an this plan, will be an inprovanent.

All techla swarms of bees, sliould be wintered in a cellar, or in a tampernteplace, inasmuch as tho animal heat necersary to kacp tlicin from perishing by cold dapende on tho number of their companione in the hive. Some good bee managers recominend uniting all tho fecbla swarme with stronger once in the fall as a matter of cconomy, as it not only asves tbe liven of the becs, but soves also, coneidarablo honoy, for it is a wall autlenticated fact, that in wintering full colonies of bees, they consuma mucli les honey in proportion to their number than feeblo onet. Bwarase of becs may bo ensily unjed by fumigatins botb lives with a littla tobacco enoko which may bo blowed iuto tho hives so ay to sicken them a little, as the vamo time tho effect of the emolse randors a same. ness of emell betwixt tho two; so thut the bee do not secun to distirguish cach other from thair own companions when llo live to bo expelled is iuvoried, and tha ona to recaivo them is set over it : As soon an tho two swarms have united in tho upper hivo, tho jower one may be taken away and tho comb preserv. ed In its perifect atato for a ngw swarm tho followiag seáon. 
OHATTER I2.

OHORVATIONo pOR gPALNo.

Bot tom boards and rentilatore ahonld be kept closed in the spring until tho weatler comes of warns to foeilitato raising young bees and proventing thoir bo ing robbed. If there ars but fow boes in the bivio, somn of tho lioles at ita entranco may be stopped to - nablo tho bee to guard tlienselves froln their enco mies taking caro at tho same time to clenr the bottom board onco or twice a week until the hivo is well ra. plonished with bees.-Boes should bo admitted litto tho drawera as coon as fruit trees aro ill blosoon.

.It is not unueual for some swarme of bee to ovaous ate their hives in tho spring and join with othore, without boing robled; the causo usually is mat of honey. I hero thought noro beus ary etarved is epring than in winter monthe.

\section{A P P E N D I X.}

The fliver is made of threo rough boardn, hnif inet thlek, seven inches wide, 24 inches lang, nailed tow getber like a cnmmun trough, open at both ends-n - trap of iron riveted on its outsicle; across the centro of each bourd; with a shank or socket to insert a rod to handto it with, so that when inverted by usous of the rod, and plaged ovor the bees whon alighting forme a kind of half-bire, which they rosdily culur. 
"Thero should bo ifrom a dozcu to twenty half-incts holes bored through the top board, so as to let tho stightling hees onter thronglt tho holes. When a small propartion of the bees aro found in tho hiver, it inay be mored a few feet fiom the limb, which inag the shaken with another rod with a hook on its end, which disengages, tho bees, and in a fow monenta the whole swarm will bo found in the hiver. By the adition of firules and joints, the lsiver may be raised in ally rnasonable height. Thus the labor of climb. ing, the usu of lacldors, and culting the limbs of pre. cisua fruit troos, is culurcly dispensed with. It liko. wiso enubles tho apiarian in largo establishments to divido out and licep separato his swarma, whicl thight otherwiso alight many in one body.

Others practice as follows, to wit: Drive down two stakes 3 fect apart, 5 or 6 yards from tho beo houge, now confino a crossbar to cach stake 2 or 3 feet from the ground. $\Lambda 12$ font board with one end resting - on this crossbar, and the other on tho ground will usually entels the bees when they swarm on its under ride, if there is no :ruit trees nor shrubbery at hand, for the bece to alight on; any person will linow how to turn over the boxd and sit an emply hive over tho bees. As boen manifust a strong desiro to alight 80 - far from the old stock as not to be intersuptod by their 1hun during their organization for anew home, caro - siust boexureised not to place the boarditoo ncar tho old hive. 
Some good bec managers hapo recommended set. thing down bushes like bean poles with the foilago on tho top, around about the apiary. for becs to alight on, which answers an cxcollont purposo where there aro notrecs at hand. But thero is another method which I havo known to sucened in calching swarms even where fruit trees sro plenty in tho immediate vicinity of the apiary, it is this: Tako a quantily of dry mullen licads, and canfino bath ends wlihem $a$ round the body, or limb of a bush in such a mannor as to look liko a sivarm of bees at a little distanec; where several of theso aro set down, scattered abous at shost distances from the npiary, the bees wiil sottlo on somo ono of them that is most shadod.-It should Bo romembered in all cases not to let the sun shino a d a beo bivo solong as to heat the board. 
9TATE OF VERMONT, I SAYUEL SwITT, Clork of Andison Coostr 68: ' He Counly Gourl fur the ssid Caunly of Addison, do hernby certify that Juhn M. Weeks of. Salisbury in said Counly hav deposiled in my uffice his orianal lotiers paien, under the seal of the Untied Siates, sign-d by Androw Jackson, Presitent of tho United Ststes, counlersigued by John Forsyth, Senrelary of Siale, aut dated the 30ih day of June, in the year 1336, granting to the suid John M. Wenks, his heirs \&c. the cxelusivo right of making, using. and rending to others to use a certaill improvement in the beo hire, for the term of fuurteen ycars, from the said $30 \mathrm{~h}$ - day of June 1836; to which is ennered a schedulo specifying
tha usid improvenient.

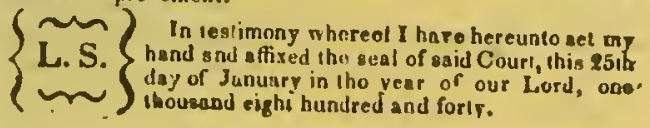

BAMUEL SWIET, CleTh. 
, 


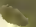

